\title{
Interaction and Interactive English Teaching in the High School Level
}

\author{
Mansoor Fahim \\ Allameh Tabataba'i University, Iran \\ Ali Seidi (Corresponding Author) \\ Islamic Azad University, Gilan-E-gharb Branch, Gilanegharb, Iran
}

\begin{abstract}
One of the main principles of education is interaction. In language classes, learners should have more autonomy to have interactions among themselves as well as with the teacher. Second language learners are more likely to achieve better levels of comprehension of the new input in their effort to communicate through interaction. Based on socio-cultural theory, language has both functions of communicative tool and a psychological tool which mediates meaning between the individual and the linguistic goal and therefore assists the cognitive development process. This study investigates interactive language teaching among the English high school teachers. The researcher investigated the effect of individual factors, gender, educational background, teacher education, and marital status of teachers on their tendency to interactive teaching. The results of the study showed that some of the above factors influence the teacher's tendency to interactive teaching.
\end{abstract}

Index Terms —interaction, interactive teaching, textbooks, teaching method

\section{INTRODUCTION}

There are many factors that are involved in education. These factors may also vary based on time, place and context. Teachers are also facing many challenges. In the 21st century, Gass (2003) asserts that education should have the following features:

- Education in schools should focus on critical thinking, creative thinking, active in-group learning, and teacher learner interaction.

- Education in schools should not be teacher-centered, learner-centered, knowledge-centered, or society-centered. Rather, it must include all these factors and should look at the issue from a holistic point of view.

The developed countries in recent decades have shifted from the traditional approaches to learning and teaching by a meticulous educational system, the excessive numbers of researches conducted have shown that traditional approaches to learning are no more working for the current time (Ellis, 1999). In Iran, traditional teaching methods such as grammar translation have been used for a long time. GTM is still used in high schools of Iran. We may also see the use of some aspects of new approaches in classrooms. However, the goal of this study is not to suggest a specific method for language teaching in high schools. Rather, we are emphasizing the benefits of interaction and interactive teaching in meeting the educational needs and gaining better educational objectives in high schools in Iran.

Sometimes, teachers face some problems in engaging students in the class activities. Teachers might think that interactive teaching is a small part of the classroom teaching along the other activities, and interactive teaching requires some extra time which is a wrong conception (Allwright, 1984). This means that they have mostly been experiencing teacher-centered classes and have provided less chance for student's autonomy and an interactive relationship between the teacher and the language learners. Interactive teaching is not limiting the control of the teachers and giving more power to students.

By teaching interactively, teachers can students to activate their prior knowledge of the content, to use it for their present and future learning tasks. Sometimes, there are some flaws in what student have learned previously, and by reviewing it teachers can provide corrective feedback for eliminating those flaws.

There are many definitions for teaching. One is that teaching is an activity, but not any kind of activity. It is an activity which is done consciously, and is designed to follow a specific objective (Littlewood, 1981). Interaction is necessary for effective teaching. Teaching has two special characteristics:

- The existence of interaction and relationship between the teacher and the learners

- Goal-oriented activities of the teachers

Teaching is not doing a set of unrelated and one-directional activities, and by considering the concept of "interaction" does not include learning from other sources such as movies, T.V, or books. What is emphasized here is interaction. There are some factors like the individual characteristics of the teachers, educational, and professional characteristics which are influential in pre-teaching, in-teaching, and post-teaching of teachers (Burns \& Myhill, 2004). Teachers should have a meticulous, goal-oriented design to make progress in the student's learning. Interactive teaching is 
referring to those more, and totally learner-centered approaches which are carefully designed to motivate students to learn and gives more responsibility to the students for their own learning.

The present study aims at investigating the following questions:

1. Do the individual characteristics of the high school male and female English teachers (such as age) influence their tendency to teach interactively?

2. Does the educational background and professional development of the high school male and female English teachers influence their tendency to teach interactively?

3. Is there any difference between the male and female high school teachers in their tendency to teach interactively?

\section{REVIEW OF LITERATURE}

In recent decades, there are been various views in the area of language teaching on the influential factors that leads classroom language learners to achieve mastery of a second or foreign language. It is mostly believed that classroom language learning is greatly dependent on the nature of the classroom interaction in order to meet the desired outcomes. This fact has been noted and given importance in the literature by different scholars (Allright, 1984; Breen and Candlin, 1980; Long, 1981). Such studies have provided important considerations for language learners for language development. Vygotsky (1978) asserts that based on the sociocultural theory, a diological approach holds that learning should be in the manner that arouse a diversity of internal developmental processes which operate just at the time of a child's interaction and cooperation with others in the environment, and these processes become internalized when they turn into a part of independent developmental achievement of the child. As a result, sociocultural and institutional realities that exist outside the classroom should be reflected as much as possible in the classroom, and classroom interaction covers the elements of negotiation, co-construction, and collaborative dialogue.

\section{Classroom interaction and its components}

\section{a. Collaborative Dialogue}

Collaborative dialogue refers to when a dialogue occurs efficiently between learner and learner or learner and assistant interaction. The potential level of development of the individual was the focus of Vygotsky rather than the individual's current level of development. Test scores might show the same level of actual development for two individuals. However, as Johnson (2000) says, these two may demonstrate different levels of potential development which is shown by their distinctive abilities and performances in solving similar problems with regard to varying assistance degrees from an adult. When learners interact with other members of their sociocultural environment including family members, friends, teachers, classmate, and coaches it leads to dialogic interaction. Vygotsky states that learning is an essential activity of the learner's self and adult's assistance or cooperation with more capable peers.

As a result, Gass (2003) says that collaborative dialogue is "a knowledge of building dialogue, in which language use and language learning can co-occur. It is language use mediating language learning. It is cognitive activity and it is social activity" (p. 227). Its realization might be in an everyday conversation format. As collaborative dialogue take a significant role in communicative language teaching, classroom interaction should also take the same role in classroom language learning which facilitates SLA development if the classroom setting take an influential role in social setting.

b. Negotiation

According to Ellis (1990), Interaction Hypothesis holds that L2 learners can acquire a new language when they encounter communicative problems which provide them with the opportunity of negotiating solutions to them. The input needs negotiated interaction to be comprehensible. This is not in line with Krashen's Input Hypothesis, which focuses on input as simplified along with contextual support as necessary for comprehensible input.

Negotiation generally is seen as discussion to find agreement. Allright (1984) asserts that interactive negotiation needs to be person-to-person communication in order to lead to satisfactory outcomes. Reading a text and analyzing it silently includes three basic processes of interpretation, expression and negotiation. Negotiation is viewed as using real life language which is related to the learner's learning purposes.

Negotiation has also an essential role in classroom interaction. When more opportunities are provided for L2 learners for negotiation of comprehension problems, they are more successful. More L2 vocabulary is learned when learners are involved in peer negotiation and interactive situations. By negotiating the input, learners reach higher vocabulary acquisition scores in doing the immediate post test, and more importantly, they kept this benefit over time (Allright, 1984). As a result, negotiation should be viewed as a $\mathrm{n}$ assistance to L2 comprehension and SLA. Negotiation modifies the students' input in classroom settings which does not always result in their immediate comprehension of meaning but through them the form is manipulated.

Classroom interaction has two main negotiated forms: face-to-face peer negotiation and corrective feedback negotiation given by the instructor. Self-negotiation might be used by some researchers as the third form of negotiation. They consider it as a kind of self-regulation or construction because it needs the high cooperation between learners themselves, and learners and teachers.

c. Co-construction

Jacoby and Ochs (1995) define co-construction as "the joint creation of a form, interpretation, stance, action, activity, identity, institution, skill, ideology, emotion or other culturally-related meaning reality" (p. 171). According to Long (1981), interactional competence refers to the language knowledge which is co-created by all those who participate in 
interaction. It is required that all the participants have the duty to make a successful and appropriate interaction in a special social context. Through face to face interaction, participants negotiate meaning and also co-construct it together in a locally specific social context.

The awareness of self-regulation is gradually constructed from dialogic interaction by the L2 learners in classroom interaction while negotiating with peers and teachers. According to Aljaafren and Lantolf (1994), "The learner becomes more consistent in using the target structure correctly in all contexts. In most cases, the individual's use of the correct target form is automatized. Whenever aberrant performance does arises, however, noticing and correcting of errors does not require intervention from someone else, so the individual is fully self-regulated" (p. 470). Classroom interaction helps in developing the ability of constructing second language acquisition.

Therefore, the organization of classroom interactively and culturally classroom is greatly important in SLA. Classroom interaction have various forms including individual activity, group activity, collaboration, closed-ended teacher questioning, teacher initiates and student answers, self-access, full-class interaction, etc. The most interactive form among these patterns is pair or group. Pair or group work has three value systems of choice, freedom and equality besides paying attention to the sociocultural and personal experience that assists students' behavior in the classroom. According to Johnson (2000), choice as an idea is inserted in the notion of pair work or group work since there is a choice of partners or groups for students; Freedom is seen since students can and have the right to talk freely in pairs or groups without the teacher's control; and equality is seen since students are equal in groups because the teacher's power is decreased or neutralized within groups.

Jones and Tanner (2002) state that in a socio-constructivist approach to interaction new knowledge is constructed and validated by learners within the classroom's social context. There must be a kind of interaction between the learner and the teaching context to come up with learning. But if we want to achieve more than a superficial level of interaction, learners must be aware that they have to meaningfully engage with the teaching, and bring themselves to the exchange rather that only being one who passively receives preformed information. A level of active participation is required by learners who take part in the development of collective understanding to achieve interactivity.

Black and Wiliam (1998) claim that there is ample evidence to indicate that moving towards fully interactive pedagogies, collective reflection and the development of consensual knowledge results in improving learning and achievement. However, the problem is imposed external assistance which makes teachers concentrate on superficial aspects of interactive teaching including pace and structure rather than pedagogies which have deeper aspects. The initiation of new technology may raise the same pressures on teachers.

\section{Realizing interaction in language classroom}

According to Ellis (1999), better results in negotiation are gained when the control of discourse is in the hands of beginner language learners than when native speaker, language teacher, or capable language speaker has the control of discourse. Ziglary (2008) says that "in the case of not controlling the discourse, the language learner either waits or abandons to speak later. Based on the socio-cultural view, if the discourse control is in the hand of the teacher, it makes learners outside the ZPD. So in the area of discourse control, the notion of topic is hidden" (p. 451).

If students are provided with tasks in the classroom, they are involved in topic not merely activity-based condition. Ellis (1999) states that in a task learners need to pay attention to what is being talked about rather than the language use. Van Lier (1988, cited Kaufman, 2004) asserts that "talk" in the classroom is concentrated on the way we say or do things, rather than on what is talked about. Activity is the term that he makes use of and emphasizes that the class must be in the form of activity or topic. It is believed that learners have control over the discourse in classrooms which are topic-oriented. Conversation or interview is the second aspect of discourse control.

Discourse is collaboratively constructed by participants who take part in conversation or interview. Ellis (1999, cited in Ziglary, 2008) states that "in language acquisition, mother provides a supportive role to the child and helps him to proceed in the discourse; whereas in the classroom, the teacher controls the discourse by providing an IRF exchange to conform the language to the goal of the activity. IRF means that the teacher initiates, learner responds and the teacher provides feedback. Another suggestion is to provide topicalisation in the classroom (p. 451). There are also other ways of bringing talking circle in the class or assure that communication is happening in the classroom in the target language. According to Johnson (1995, cited in Larsen-Freeman \& Long 1991), the basic features of an acquisition rich classroom are providing a context for language use, giving chances to learners to make personal meanings, assisting learners to take part in activities which are beyond their current level of proficiency, and presenting a series of contexts that cover full performance in the target language.

\section{METHOD}

In order to carry out this study a sample of 60 high school English language teacher have been selected. In this sample, 30 of them were male and 30 were females. They ranged from 23 to 40 years old and had different teaching experiences from 1 to 25 years. For data gathering a Likert-scale questionnaire consisting of 16 items was designed and was later validated in a pilot study. For measuring the reliability of the questionnaire, it was given to group of high school teachers and after giving it to the same group after a while, the estimated reliability was $/ 085$, which shows that the questionnaire is reliable. Both descriptive and inferential statistics were used for interpreting the gathered data. 


\section{Results}

In this part we present the data that has been gathered. The following table gives the frequency of the answers given to all the items of the questionnaire.

\begin{tabular}{|c|c|c|c|c|c|c|}
\hline & Questions & $\begin{array}{l}\text { Very } \\
\text { Little }\end{array}$ & $\begin{array}{l}\text { A } \\
\text { Little }\end{array}$ & Somehow & Much & Very Much \\
\hline 1 & $\begin{array}{l}\text { How much is the age of the teacher (between } 20 \text { to 30) influential in her } \\
\text { tendency towards interactive teaching? }\end{array}$ & 20 & 9 & 4 & 17 & 9 \\
\hline 2 & $\begin{array}{l}\text { How much is the age of the teacher (between } 30 \text { to 40) influential in her } \\
\text { tendency towards interactive teaching? }\end{array}$ & 20 & 10 & 7 & 17 & 6 \\
\hline 3 & $\begin{array}{l}\text { How much is the marital status of the high school teachers is influential in } \\
\text { their tendency towards interactive teaching? }\end{array}$ & 16 & 11 & 8 & 17 & 8 \\
\hline 4 & $\begin{array}{l}\text { How much is the marital status of the secondary school teachers is influential } \\
\text { in their tendency towards interactive teaching? }\end{array}$ & 19 & 8 & 5 & 18 & 10 \\
\hline 5 & $\begin{array}{l}\text { How much is the high school school teacher's university degree (Diploma, B. } \\
\text { a, Ma) influential in their tendency towards interactive teaching? }\end{array}$ & 25 & 14 & 5 & 11 & 5 \\
\hline 6 & $\begin{array}{l}\text { How much is the secondary school teacher's university degree (Diploma, B. } \\
\text { a, Ma) influential in their tendency towards interactive teaching? }\end{array}$ & 22 & 15 & 4 & 14 & 5 \\
\hline 7 & $\begin{array}{l}\text { Do you think that a high school teacher with the TEFL degree (not literature, } \\
\text { or translation) can teach English better in high school? }\end{array}$ & 20 & 11 & 4 & 18 & 7 \\
\hline 8 & $\begin{array}{l}\text { Do you think that a secondary school teacher with the TEFL degree (not } \\
\text { literature, or translation) can teach English better in high school? }\end{array}$ & 26 & 10 & 7 & 12 & 5 \\
\hline 9 & $\begin{array}{l}\text { Is it important where a high school English teacher has graduated from in } \\
\text { her tendency towards interactive teaching? }\end{array}$ & 13 & 21 & 19 & 7 & 0 \\
\hline 10 & $\begin{array}{l}\text { Is it important where a secondary school English teacher has graduated } \\
\text { from in her tendency towards interactive teaching? }\end{array}$ & 7 & 21 & 20 & 12 & 0 \\
\hline 11 & $\begin{array}{l}\text { Is it important when a high school English teacher has been graduated (in } \\
\text { terms of experience) in her tendency towards interactive teaching? }\end{array}$ & 3 & 2 & 15 & 21 & 19 \\
\hline 12 & $\begin{array}{l}\text { Is it important when a secondary school English teacher has been graduated } \\
\text { (in terms of experience) in her tendency towards interactive teaching? }\end{array}$ & 29 & 10 & 15 & 6 & 0 \\
\hline 13 & $\begin{array}{l}\text { How much teacher education programs are useful increasing the high school } \\
\text { teacher's tendency towards interactive teaching? }\end{array}$ & 19 & 8 & 5 & 18 & 10 \\
\hline 14 & $\begin{array}{l}\text { How much teacher education programs are useful increasing the secondary } \\
\text { school teacher's tendency towards interactive teaching? }\end{array}$ & 23 & 10 & 8 & 12 & 7 \\
\hline 15 & Is interactive language teaching useful for high school level? & 22 & 10 & 5 & 17 & 6 \\
\hline 16 & Is interactive language teaching useful for secondary school level? & 16 & 10 & 8 & 16 & 10 \\
\hline
\end{tabular}

Beside the frequency of the answers, a Chi-Square test was also conducted for each item of the questionnaire. The results obtained from some the items are presented in this part. The first item is about the relationship between the individual factors of the high school school teachers (such as age, and marital status) and the tendency towards interactive teaching. The results of the Pearson Chi-Square showed the value of 22.5 , it is represented as: $(\mathrm{P}(16)=$ 22.5>9.49). This shows that individual factors influence the teacher's tendency towards interactive teaching. The following table shows this:

\begin{tabular}{|l|l|l|l|}
\hline Asymp. Sig. (2-tailed) & df & Value & \\
\hline Pearson Chi-Square & $22.548(\mathrm{a})$ & 16 & .126 \\
\hline Likelihood Ratio & 28.272 & 16 & .029 \\
\hline Linear-by-Linear Association & .219 & 1 & .639 \\
\hline Number of Valid Cases & 60 & & \\
\hline
\end{tabular}

The second item presented here is about the effect of the high school teacher's educational background and their tendency to teach English interactively. The results of the Pearson Chi-Square showed the value of 17.4, it is represented as: $(\mathrm{P}(16)=17.4>9.49)$. This shows that the educational background influences the teacher's tendency towards interactive teaching.

\begin{tabular}{|l|l|l|l|}
\hline Asymp. Sig. (2-tailed) & df & Value & \\
\hline Pearson Chi-Square & 17.474 (a) & 16 & .356 \\
\hline Likelihood Ratio & 20.566 & 16 & .196 \\
\hline Linear-by-Linear Association & .173 & 1 & .678 \\
\hline Number of Valid Cases & 60 & & \\
\hline
\end{tabular}

The second item presented here is about the effect of the high school teacher education programs and their tendency to teach English interactively. The results of the Pearson Chi-Square showed the value of 18.5, it is represented as: (P $(16)=18.5>9.49)$. This shows that teacher education programs influences the teacher's tendency towards interactive teaching. 


\begin{tabular}{|l|l|l|l|}
\hline Asymp. Sig. (2-tailed) & df & Value & \\
\hline Pearson Chi-Square & 18.576 & 16 & .282 \\
\hline Likelihood Ratio & 19.404 & 16 & .248 \\
\hline Linear-by-Linear Association & .019 & 1 & .889 \\
\hline Number of Valid Cases & 60 & & \\
\hline
\end{tabular}

One of the major questions of the study was whether interactive teaching is used more by the high school English teachers or the secondary school English teachers. In this regard, a T-test was conducted on the data and the result showed the value of $(\mathrm{p}=.000)$. It is represented as: $(\mathrm{P}(59)=.000>.05$. This shows that interactive teaching is used more by high school English teachers. The results are represented in the following table.

ONE SAMPLE T-TEST

\begin{tabular}{|l|l|l|l|l|l|l|}
\hline Test Value = 0 & $\begin{array}{l}\text { Mean } \\
\text { Difference }\end{array}$ & Sig. (2. tailed) & df & t & \\
\cline { 1 - 6 } $\begin{array}{l}\text { 95\% Confidence } \\
\text { Interval of the Difference }\end{array}$ & Lower & 2.6000 & .000 & 59 & 13.870 & $\begin{array}{l}\text { Interactive teaching in high school } \\
\text { and secondary school teachers }\end{array}$ \\
\hline Upper & 2.2249 & & & \\
\hline 2.9751
\end{tabular}

The results of the study showed that teaching is context based and we cannot use a one design, syllabus, method or curriculum for different situations. There the ministry of education in Iran should make some programs for different regions, levels and contexts. This does not reject a national school curriculum. Rather, our suggestion is to involve these smaller, local programs into the national, general framework. The present study suggests the following implications to be implemented by the teachers and policy makers for the high school context:

- Using various learning materials and approach

- Involving and engaging students more in the process of learning instead of a teacher centered class

- Besides teaching, constant research project should be conducted to be always aware of the changes that occur in students, teachers, society, etc.

- Providing teacher education programs for the high school teachers one a year or one in a couple of years

- Engage in a continuous process of developing the teaching skills based on the recent research findings

- Teachers' motivation to teach interactively should be increased by providing their needs

- Peer observation should happen in the high school context and it should involve encouragement for their improvements.

\section{CONCLUSION}

In language teaching the classroom environment in which learner are involved in has to be seen as an essential part of brother contexts such as the broader sociocultural and institutional context. Its role is to provide a context in which learners can pay attention to various discursive practices. Moreover, the classroom environment and its interactions should be able to reflect the existing social reality outside the classroom. In this regard, classroom interaction has essentially the role of cooperative negotiation and co-constructive work so that L2 learners achieve language development as well as self-development. If teachers, students, and researchers work cooperatively on the importance of classroom interaction, the obtained results will surely assist language teaching. There is certain need of mutual understanding of an effective interaction among the teachers and the students. As a result, teachers should act as facilitators for building this effective interaction so that interactive teaching comes more into practice.

\section{REFERENCES}

[1] Aljaafreh, A., \& Lantolf, J. P. (1994). Negative feedback as regulation and second language learning in the zone of proximal development. Modern Language Journal 78 (1), 465-483.

[2] Allwright, D. (1984). The importance of interaction in classroom language learning. Applied Linguistics, 5 (2), $156-171$.

[3] Black, P. J., \& Wiliam, D. (1998). Assessment and classroom learning. Assessment in Education: Principles Policy and Practice, 5 (1), 7-73.

[4] Breen, M. P., \& Candlin, C. N. (1980). The essentials of a communicative curriculum. Applied Linguistics, 1 (2), 89-112.

[5] Burns, C., \& Myhill, D. (2004). Interactive or inactive? A consideration of the nature of interaction in whole class teaching. Cambridge Journal of Education, 34 (1), 35-49.

[6] Eliss, R. (1990). Instructed second language acquisition. Oxford: Basil Blackwell.

[7] Ellis, R. (1999). Learning a second language through interaction. Amsterdam: John Benjamins Publishing Company.

[8] Gass, S. M. (2003). Input and interaction. In C. J. Doughty \& M. H. Long (Eds.), The handbook of second language acquisition (pp. 224-255). Oxford: Blackwell.

[9] Jacoby, S., \& Ochs, E. (1995). Co-construction: An Introduction. Research on Language and Social Interaction, 28 (1), 171 183.

[10] Johnson, M. (2000). Interaction in oral proficiency interview: Problems of validity. Pragmatics, 10 (2), 215-231.

[11] Jones, S., \& Tanner, H. (2002). Teachers' interpretations of effective whole class interactive teaching in secondary classrooms. Educational Studies, 28 (3), 265-274. 
[12] Kaufman, D. (2004). Constructivist issues in language learning and teaching. Annual Review of Applied Linguistics, 24, 303319.

[13] Larsen-freeman, D., \& Long, M. H. (1991). An introduction to second language acquisition research. London: Longman.

[14] Littlewood, W. (1981). Communicative language teaching: An introduction. Cambridge: Cambridge University Press.

[15] Long, M. H. (1981). Input, interaction and second language acquisition. In S. Winitz (Eds.), Native language and foreign language acquisition (pp. 259-278). New York: New York Academy of Sciences.

[16] Vygotsky, S. (1978). Mind in society: The development of higher psychological process. Cambridge: Cambridge University Press.

[17] Ziglary, L. (2008). The role of interaction in L2 acquisition: An emergentist perspective. European Journal of Scientific Research, 23 (3), 446-453.

Mansoor Fahim was born in Iran in 1946. He received a Ph.D. in TEFL (Teaching English as a Foreign Language) from Islamic Azad University in Tehran, Iran in 1994, an M.A. in General Linguistics from Tehran University in Tehran, Iran in 1978, and a B.A. in English Translation from Allameh Tabataba" i University in Tehran, Iran in 1975.

As for his professional background, he was the chairman of the EFL department at Allameh Tabataba" i University from 2003 to 2007 and a member of the faculty of English Language and Literature at Allameh Tabataba" i University in Tehran, Iran from 1979 to 2008 when he was retired as an associate professor of TEFL. He has also taught English at a welter of universities and language schools. At present, he runs Psycholinguistics, Applied Linguistics, First and Second Language Acquisition, and Discourse Analysis courses at M.A. and Ph.D. levels at a number of universities in Iran, including Allameh Tabataba" i and Islamic Azad Universities. Dr. Mansoor Fahim is currently a member of the editorial board of the Iranian journal of Applied Linguistic Studies, Sistan \& Baloochestan University, Iran; Journal of Language Studies, Shahrekord University, Iran; and Journal of English Language Studies, Islamic Azad University, Tehran, Iran.

Ali Seidi was born in Kermanshah, Iran in 1987. He obtained his MA in Teaching English as Foreign Language (TEFL) from Iran University of Science and Technology in 2011. Currently, he is a Ph.D. student in TEFL at Islamic Azad University, Science and Research Branch, Tehran, Iran. He is the head of English department and a faculty member at Islamic Azad University, Gilanegharb Branch. He has published articles in different journals. His research interests are CDA, Sociocultural studies, identity, material development, and psychological studies. 